Article

\title{
Variations in Soil Water Content and Evapotranspiration in Relation to Precipitation Pulses within Desert Steppe in Inner Mongolia, China
}

\author{
Yifan Song ${ }^{1}$, Yajing Lu ${ }^{2, *}$, Zhongxiao Guo ${ }^{1}$, Xiaomin $\mathrm{Xu}^{1}{ }^{1}$, Tiejun Liu ${ }^{1}$, Jun Wang ${ }^{1}$, \\ Wenjun Wang ${ }^{1}$, Weigang Hao ${ }^{1}$ and Jian Wang ${ }^{1}$ \\ 1 State Key Laboratory of Simulation and Regulation of Water Cycle in River Basin, China Institute of Water \\ Resources and Hydropower Research, Beijing 100038, China; songyf@iwhr.com (Y.S.); \\ guozx@iwhr.com (Z.G.); xuxiaomin82@163.com (X.X.); mksltj@126.com (T.L.); slwj1988@163.com (J.W.); \\ wangwj@iwhr.com (W.W.); hao_weigang@163.com (W.H.); dhy8063@163.com (J.W.) \\ 2 Department of Disaster Prevention and Reduction, Beijing Water Science and Technology Institute, \\ Beijing 100048, China \\ * Correspondence: luciaharry@163.com; Tel.: +86-10-68735860
}

Received: 4 December 2018; Accepted: 17 January 2019; Published: 24 January 2019

\begin{abstract}
Neither single nor discontinuous hydrological observation data can truly reflect periodic changes in soil moisture under natural conditions or interrelationships between various water sources. Therefore, in this study, precipitation pulse characteristics and variations in the soil water content (SWC) and actual evapotranspiration $\left(\mathrm{ET}_{\mathrm{a}}\right)$ in relation to pulses are explored through a field multi-water continuous observation system set in desert steppe in Inner Mongolia, China. A comparison between precipitation events in the growing seasons of 2016 and 2017 shows that precipitation events that are greater than $10 \mathrm{~mm}$ are the main cause of dramatic interannual precipitation variations in this region. A single small precipitation event has a limited impact on SWC and provides no obvious increase in the SWC within the top $10 \mathrm{~cm}$ soil layer. The precipitation interval ratio $(\mathrm{P} / \mathrm{I})$ is suitable for comparing water stresses of different drying-wetting cycles, and correlations between soil layers are found to be closer in humid years than in dry years. In this study, three modes of interpulse $\mathrm{ET}_{\mathrm{a}}$ in the desert steppe are discussed: a stable $\mathrm{ET}_{\mathrm{a}}$ mode under a water-sufficient condition, an attenuation $\mathrm{ET}_{\mathrm{a}}$ mode, and a stable $\mathrm{ET}_{\mathrm{a}}$ mode under extreme drought conditions.
\end{abstract}

Keywords: precipitation pulses; soil water content; actual evapotranspiration; desert steppe; precipitation interval ratio

\section{Introduction}

Arid and semiarid ecosystems are some of the most sensitive and fragile ecosystems, and as such, they are severely affected by climate change and human activity [1-3]. Available water is the most vital limiting factor, and in such areas, the amount, timing, and intensity of precipitation events are highly intermittent and unpredictable on both temporal and spatial scales [4-6], also known as precipitation pulses [7,8]. Resource pulses, which are triggered by precipitation pulses, are generally the core driving force behind ecosystem succession in arid and semiarid areas [9-11].

Desert steppe is a significant type of arid and semiarid ecosystem [12-14], and it acts as an ecological barrier, as it is situated close to wind and sand sources $[15,16]$. Because it is a zone where grassland transitions to desert, it is extremely fragile in the context of climate change and human activity $[17,18]$. The main vegetation types in desert steppe ecosystems are herbs and shrubs with shallow roots, and most of the substance (water, nutrient element, etc.), energy exchanges, and physiological activities occur in this shallow root layer [19]. Limited soil moisture is a key driving 
factor that governs these substance and energy processes in the root zone [20]. Precipitation pulses do not directly affect ecosystem productivity, but they do affect vegetation and microbial activity when transferred into the soil water through vegetation canopy interception and soil buffering [21,22]. Runoff and deep infiltration at a watershed scale account for only a small fraction of the annual water budget in dryland ecosystems [23], and most of the precipitation enters the soil and it is dissipated by evapotranspiration or absorbed by plants and microorganisms [24-27]. However, even subtle differences in precipitation amounts, intensity, and timing can lead to different water cycle processes [28], which in turn influence the substance and energy exchange processes [29]. Therefore, studying the water cycle mechanisms resulting from different precipitation events is of great ecological interest [30,31].

Obtaining complete and continuous field data is key to analyzing eco-hydrological processes in arid and semiarid areas [8]. The hydrological cycle in arid and semiarid ecosystems is nonlinear, involves multi-processes [5,9], and has high coupling characteristics [32]. Therefore, any changes in the water status are the result of multiple factors, and discontinuous monitoring of single hydrological processes generally cannot reflect the mutual feedback processes of multiple water sources (precipitation, soil water, evapotranspiration) [33]. Although many studies have noted a periodicity (day, season, and year) of some hydrological processes in the water cycle, such as soil water dynamics and evapotranspiration processes [34], the discontinuous monitoring method has been used in many studies when obtaining these periodic data; for example, using time domain reflectometry (TDR) and micro lysimeter to obtain the soil water content (SWC) and actual evapotranspiration $\left(\mathrm{ET}_{\mathrm{a}}\right)$ data. However, such monitoring methods use a short monitoring period, and more importantly, they ignore periodic changes in hydrological processes. In general, therefore, they are unable to reflect the true state of hydrological factors under natural conditions. Furthermore, when compared with our understanding of the horizontal distribution of soil water, our understanding about the vertical dynamics of soil water in dryland ecosystems is limited [8]. It is thus extremely important to continually and synchronously acquire information on multi-water change processes to enable coherent analyses of the hydrological cycle in arid and semiarid ecosystems and the strategies that vegetation and microbes use when utilizing water and nutrients.

In this study, a multi-water joint observation system is established to analyze the dynamics of SWC and $\mathrm{ET}_{\mathrm{a}}$ following precipitation pulses in the desert steppe of Inner Mongolia. The main objectives of this study are to: (1) recognize the features of precipitation events in different precipitation years; (2) discuss the dynamics of SWC and the correlation between the SWC in different soil layers under different precipitation situations; (3) investigate the reaction of shallow root vegetation $\mathrm{ET}_{\mathrm{a}}$ on precipitation pulse events and explore $\mathrm{ET}_{\mathrm{a}}$ modes during dry interpulse periods; and, (4) analyze the multi-water coupling process that is caused by precipitation pulses.

\section{Materials and Methods}

\subsection{Study Site}

The study site is located at the State Key Laboratory of Simulation and Regulation of the Water Cycle in River Basins, the Xilamuren Desert Steppe Grassland Water Cycle, and Ecological Restoration Experimental Station (hereinafter referred to as "station", $41^{\circ} 21^{\prime} \mathrm{N}, 111^{\circ} 12^{\prime} \mathrm{E}, 1600 \mathrm{~m}, 22 \mathrm{~km}^{2}$, Figure 1). The station is located in Darhan Muminggan Joint Banner (DMJB). The soil at the station is a Haplic kastanozem; the main vegetation includes Stipa breviflora, Stipa kryloyii, Aneurolepidium chinense, Agropyron cristatum, Kochia prostrate, and Artemisia frigida, and the constructive species is natural Stipa capillata (which has roots that are generally not deeper than $40 \mathrm{~cm}$ ); average annual precipitation at the station is $282.9 \mathrm{~mm}$; the average annual temperature is $2.6^{\circ} \mathrm{C}$; the fractional vegetation coverage is $20-45 \%$; and, the maximum biomass appears in mid-to-late August. 


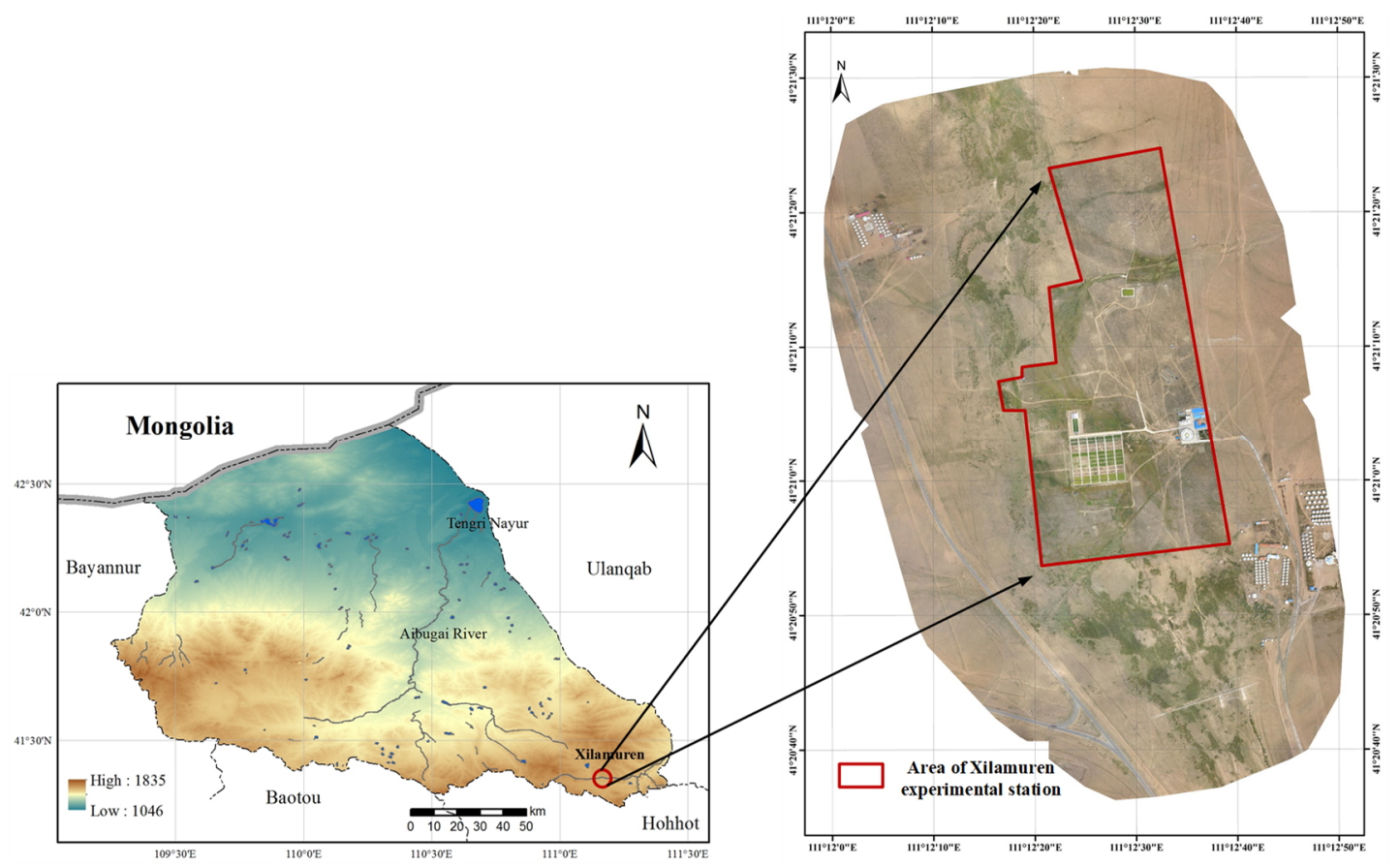

Figure 1. Geolocation and digital elevation of study site.

\subsection{Data Sources and Methods}

Data of precipitation, temperature, $\mathrm{SWC}$, and $\mathrm{ET}_{\mathrm{a}}$ were obtained from field observations conducted at the station. The soil moisture gauge, large-scale weighing lysimeter, rain gauge, and ENVIS (Environmental Information System, IMKO GmbH, Ettlingen, Germany), an ecological meteorological gradient observation system were placed adjacent to each other (Figure 2) and together they comprised the multi-water joint observation system. The soil moisture probes were self-recording layered soil moisture meters (HZR80S6; BJHzn Technology Co., Ltd., Beijing, China, accuracy: $\pm 0.1 \%$ ) buried in five different soil layers at depths of $10 \mathrm{~cm}, 20 \mathrm{~cm}, 30 \mathrm{~cm}, 40 \mathrm{~cm}$, and $50 \mathrm{~cm}$ with recording intervals of $4 \mathrm{~h}$. A bucket type rain gauge (BJHzn Technology Co., Ltd., China, Beijing, accuracy: $\pm 0.2 \mathrm{~mm}$ ) with a recording interval of $1 \mathrm{~h}$ was placed near the soil moisture gauge. $\mathrm{ET}_{\mathrm{a}}$ data were obtained with a large-scale weighing lysimeter ( $\mathrm{i}^{\prime}$ an University of Technology, Xi'an, China, specifications: $2 \mathrm{~m} \times 2 \mathrm{~m} \times 2 \mathrm{~m}$; weighing system resolution: $\pm 0.02 \mathrm{~mm}$; accuracy $\pm 0.1 \mathrm{~mm}$ ) at a recording interval of $1 \mathrm{~h}$. The ENVIS ecological meteorological gradient observation system was used to obtain temperature data during the study period, and to check precipitation data from the rain gauge. Measured precipitation, $\mathrm{SWC}, \mathrm{ET}_{\mathrm{a}}$, and temperature data were collected at the station during the growing seasons from April to October in 2016 and 2017 to analyze soil moisture and vegetation evapotranspiration dynamics during this period and their responses to precipitation pulses. Data were preprocessed by MATLAB R2018a software (MathWorks, Natick, MA, USA); data of SWC and hourly temperature were averaged to obtain daily data, while precipitation and $\mathrm{ET}_{\mathrm{a}}$ were summed by hourly data to generate daily data. The data statistics and analysis were performed while using IBM SPSS Statistics 19 (IBM, Armonk, NY, USA) and Excel software (Microsoft, Redmond, WA, USA) [15]. 


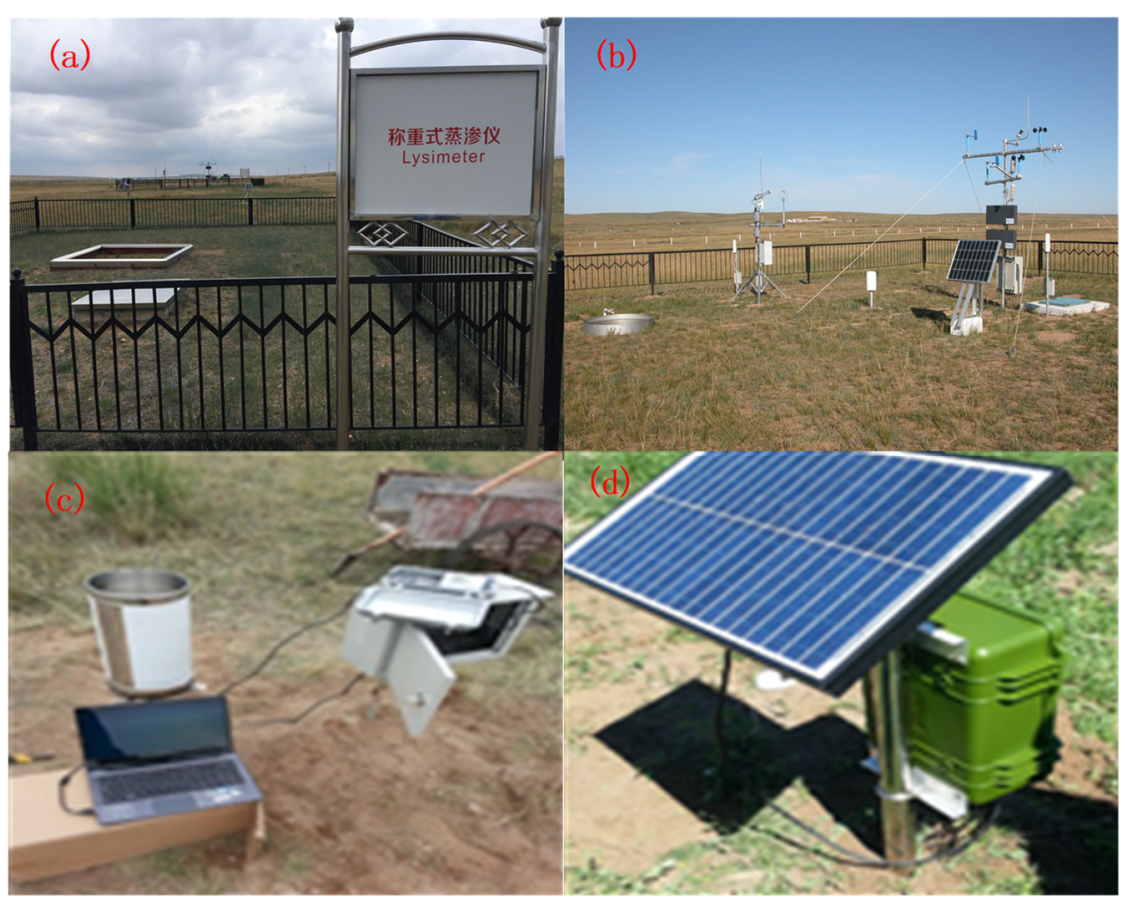

Figure 2. Field multi-water joint observation system: (a) large-scale auto-weighing lysimeter, (b) Environmental Information System (ENVIS) ecological meteorological gradient observation system, (c) bucket type rain gauge, and (d) self-recording layered soil moisture meter.

\section{Results and Discussion}

\subsection{Precipitation Characteristics Analysis in Different Precipitation Situations}

Precipitation amounts at the study site during the growing seasons (April to October) of 2016 and 2017 were $294.3 \mathrm{~mm}$ and $206 \mathrm{~mm}$, respectively. According to overall precipitation anomaly data recorded by the Xilamuren weather station over the past 30 years, these two years can be defined as a humid year (2016) and a drought year (2017), respectively. The average temperature in both years during the two growing seasons was $14.4^{\circ} \mathrm{C}$ (Figure 3). 

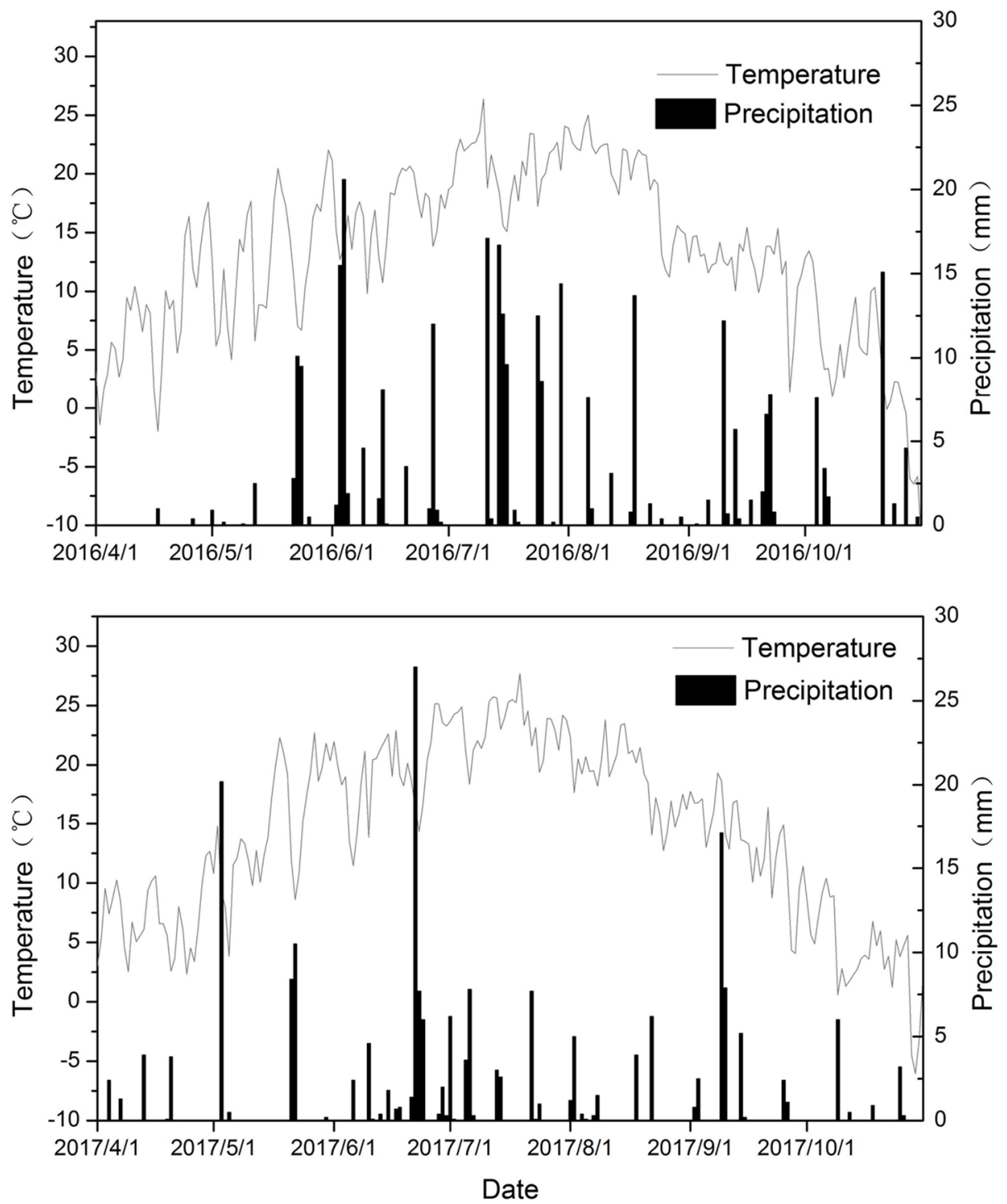

Figure 3. Precipitation and temperature during growing season in different precipitation years.

\subsubsection{Amount and Number of Days of Precipitation during Different Precipitation Years}

The precipitation characteristics of each month in different precipitation years are shown in Table 1. There was a smaller difference in the number of precipitation days (60 and 55 days, respectively) than that in the amount of precipitation (294.3 and $206 \mathrm{~mm}$, respectively) during the growing seasons of 2016 and 2017. The maximum number of precipitation days occurred in June in both years $(13 \mathrm{~d}$ and $14 \mathrm{~d}$, respectively). For monthly precipitation during the growing season, the maximum precipitation at the study site in 2016 occurred in July $(93.2 \mathrm{~mm}, 31.7 \%)$, while that in 2017 occurred in June (55.6 mm, $27.0 \%)$. When considering the amount of water that is required by vegetation during the growing seasons at the study site (June, July, and August are vigorous growth periods), greater water stress was experienced in 2017 than in 2016. 
Table 1. Precipitation and the number of rain days during the growing season in different precipitation years.

\begin{tabular}{ccccc}
\hline \multirow{2}{*}{ Month } & \multicolumn{2}{c}{$\mathbf{2 0 1 6}$} & & $\mathbf{2 0 1 7}$ \\
\cline { 2 - 5 } & Precipitation $\mathbf{( m m ) / \%}$ & Rain Days (d) & Precipitation (mm)/\% & Rain days (d) \\
\hline April & $1.4 / 0.5$ & 2 & $11.5 / 5.6$ & 5 \\
May & $26.6 / 9.0$ & 8 & $39.8 / 19.3$ & 5 \\
June & $71.2 / 24.2$ & 13 & $55.6 / 27.0$ & 14 \\
July & $93.2 / 31.7$ & 11 & $32.4 / 15.7$ & 10 \\
August & $28.4 / 9.7$ & 8 & $18.6 / 9.0$ & 8 \\
September & $39.3 / 13.4$ & 11 & $37.2 / 18.1$ & 8 \\
October & $34.2 / 11.6$ & 7 & $10.9 / 5.3$ & 5 \\
Growing season (mm) & 294.3 & 60 & 206 & 55 \\
\hline
\end{tabular}

Note: \% here stands for the percentage of the monthly precipitation to the growing season precipitation.

\subsubsection{Precipitation Characteristics of Precipitation Events at Different Levels}

Due to the stratified utilization characteristics of desert vegetation in relation to precipitation pulses, precipitation events at different levels have differing effects on desert ecosystems. The statistics for precipitation days and precipitation amounts during precipitation events at different levels in 2016 and 2017 are shown in Figure 4. In both years (humid and drought year), the majority of precipitation events were classified as small precipitation events of 0-5 $\mathrm{mm}$. In both 2016 and 2017, the percentage of $0-5 \mathrm{~mm}$ precipitation events were $65.0 \%$ (39 d) and $72.7 \%(40 \mathrm{~d})$, respectively. Affected by strong evaporation and vegetation interception, precipitation amounts of $0-5 \mathrm{~mm}$ have only a slight surface moistening effect and a limited effect on microbial respiration on the soil surface, vegetation carbon fixing, and biomass accumulation [5,35]. A comparison between different precipitation years shows that the main differences occurred in precipitation events of more than $10 \mathrm{~mm}$. Days and amounts of precipitation events of more than $10 \mathrm{~mm}$ in 2016 and 2017 were $12 \mathrm{~d}(172.5 \mathrm{~mm})$ and $4 \mathrm{~d}(74.8 \mathrm{~mm})$, respectively, and these events occurred mainly in June to August. Previous studies have confirmed that precipitation events greater than $10 \mathrm{~mm}$ are significant for arid and semiarid ecosystems [5-7]. The difference in the occurrence of precipitation events $>10 \mathrm{~mm}$ is the main reason for dramatic interannual variations in precipitation, and also one of the main features of precipitation pulses in arid and semiarid areas.
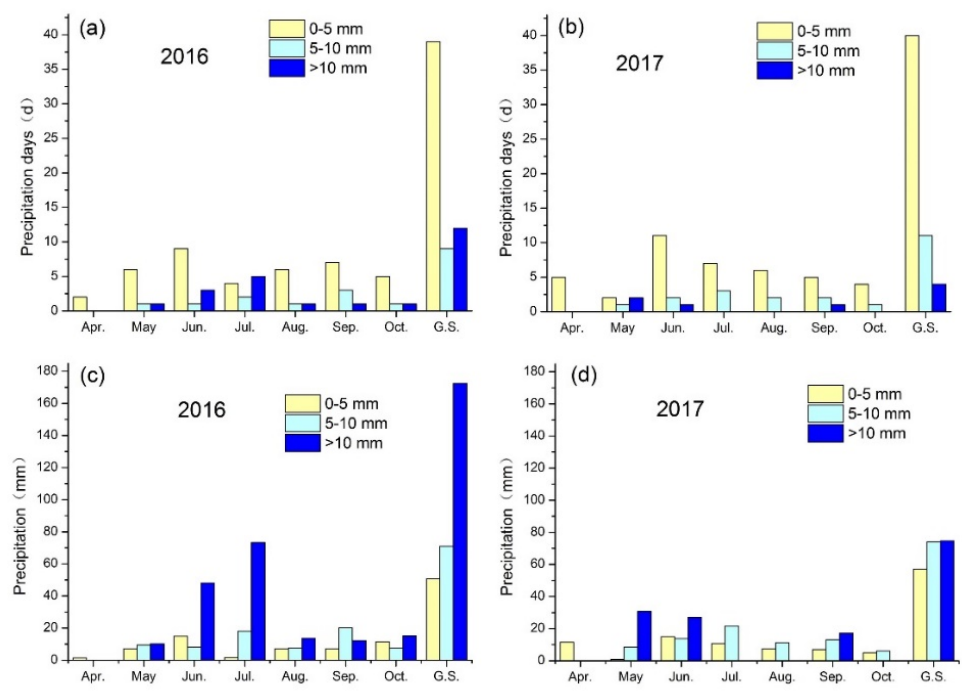

Figure 4. Number of precipitation days and amounts of precipitation (at different levels) in different precipitation years. (a) Monthly precipitation days during growing season in 2016; (b) monthly precipitation days during growing season in 2017; (c) amount of monthly precipitation during growing season in 2016; and, (d) amount of monthly precipitation during growing season in 2017. G.S. is the abbreviation for growing season. 


\subsubsection{Precipitation Interval Ratio in Different Precipitation Years}

\section{Precipitation Interval}

In addition to the amount and intensity of precipitation, the timing of precipitation is also a significant factor affecting the distribution of soil moisture and vegetation growth. Precipitation timing not only refers to the occurrence time and duration of the precipitation process, but more importantly, it refers to the duration and distribution of intervals between precipitation events. Extreme variability or unpredictability of precipitation intervals are other key features of precipitation pulses in arid and semiarid areas [36,37], and the drying-wetting cycle determined by precipitation amounts and intervals directly influences the substance and energy cycle in arid and semiarid ecosystems.

In this respect, a single small precipitation event (precipitation $<5 \mathrm{~mm}$ ) has a short duration and a limited impact on soil moisture at depth (only the surface soil layer is affected). Therefore, only the precipitation intervals of events of precipitation $>5 \mathrm{~mm}$ are discussed in this paper, and continuous daily precipitation events are merged (including continuous small precipitation events with a total amount of more than $5 \mathrm{~mm}$ ). Table 2 shows that for both the entire growing season and the vigorous vegetation growth period from June to August, the precipitation intervals were longer in the drought year of 2017 than in the humid year of 2016, and the mean amount of precipitation during each event was lower.

Table 2. Mean precipitation intervals in different precipitation years.

\begin{tabular}{ccccc}
\hline \multirow{2}{*}{ Year } & Period & Rain Days (d) & Mean Precipitation Intervals (d) & Mean Precipitation per Event (mm/d) \\
\hline \multirow{2}{*}{2016} & June-August & 9 & 7.7 & 19.7 \\
& Growing season & 16 & 10.5 & 16.4 \\
\hline \multirow{2}{*}{2017} & June-August & 7 & 10.3 & 11.2 \\
& Growing season & 12 & 16.4 & 12.8 \\
\hline
\end{tabular}

Precipitation Interval Ratio (P/I)

To compare differences between wet and dry hydrological years, the precipitation interval ratio $(\mathrm{P} / \mathrm{I})$, which is the ratio of precipitation $(\mathrm{P})$ to the precipitation interval $(\mathrm{I})$, is introduced to reflect the distribution of drying-wetting cycles in different precipitation years, as shown in Figure 5.

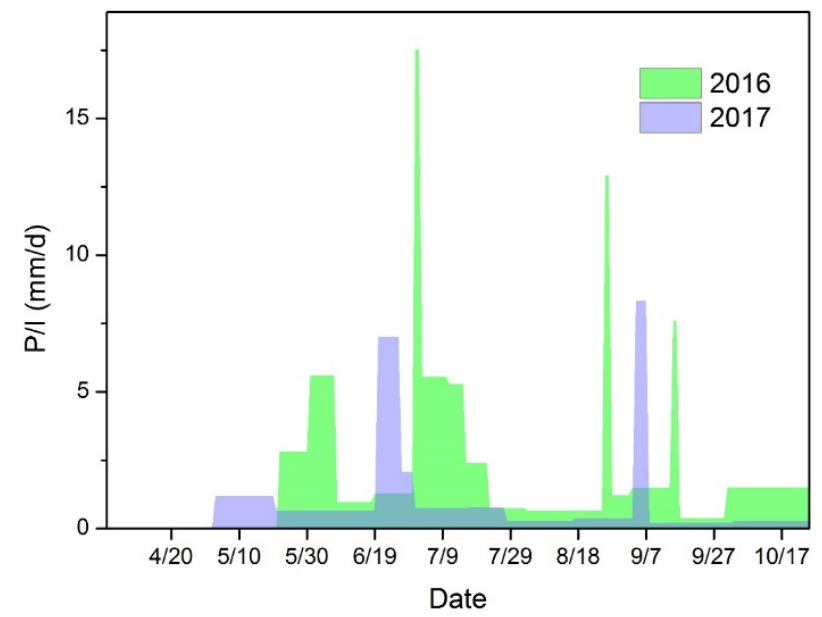

Figure 5. Precipitation interval ratio $(\mathrm{P} / \mathrm{I})$ during the growing season in different precipitation years. $\mathrm{P} / \mathrm{I}$ indicates precipitation interval ratio $(\mathrm{mm} / \mathrm{d})$.

In terms of the definition of precipitation interval ratio, in a drying-wetting cycle, the greater the ratio is, the more water can be used by vegetation in the precipitation interval, and hence the less the water stress is, and vice versa. With this parameter, different precipitation events and subsequent 
precipitation intervals can be directly compared as drying-wetting cycles. The ratio can then reflect the drought conditions in different drying-wetting cycles. Figure 5 shows that the precipitation interval ratios during the humid year 2016 were concentrated more in the vigorous vegetation growth period as compared to that of the drought year 2017, which is in agreement with the naturally synchronizing characteristics of high temperature and rich precipitation during vegetation growth in arid and semiarid areas. Therefore, this situation is more beneficial for the accumulation of biomass. Figure 5 also indicates that the larger P/I ratio in the drought year of 2017 occurred at the beginning (June) and the end (September) of the vigorous growth period. However, continuous drought occurred during the vigorous growth period. Unreasonable distribution of precipitation events and precipitation intervals made 2017 the most arid year recorded at the study site in recent years. The precipitation interval ratio also shows that, in addition to the amount of precipitation, the annual distribution of drying-wetting cycles is also important when analyzing drought.

\subsection{SWC Dynamics in Different Precipitation Years}

\subsubsection{Variations in SWC Characteristics in Different Precipitation Years}

Figure 6 and Table 3 show the dynamics of SWC in each soil layer in different precipitation years.
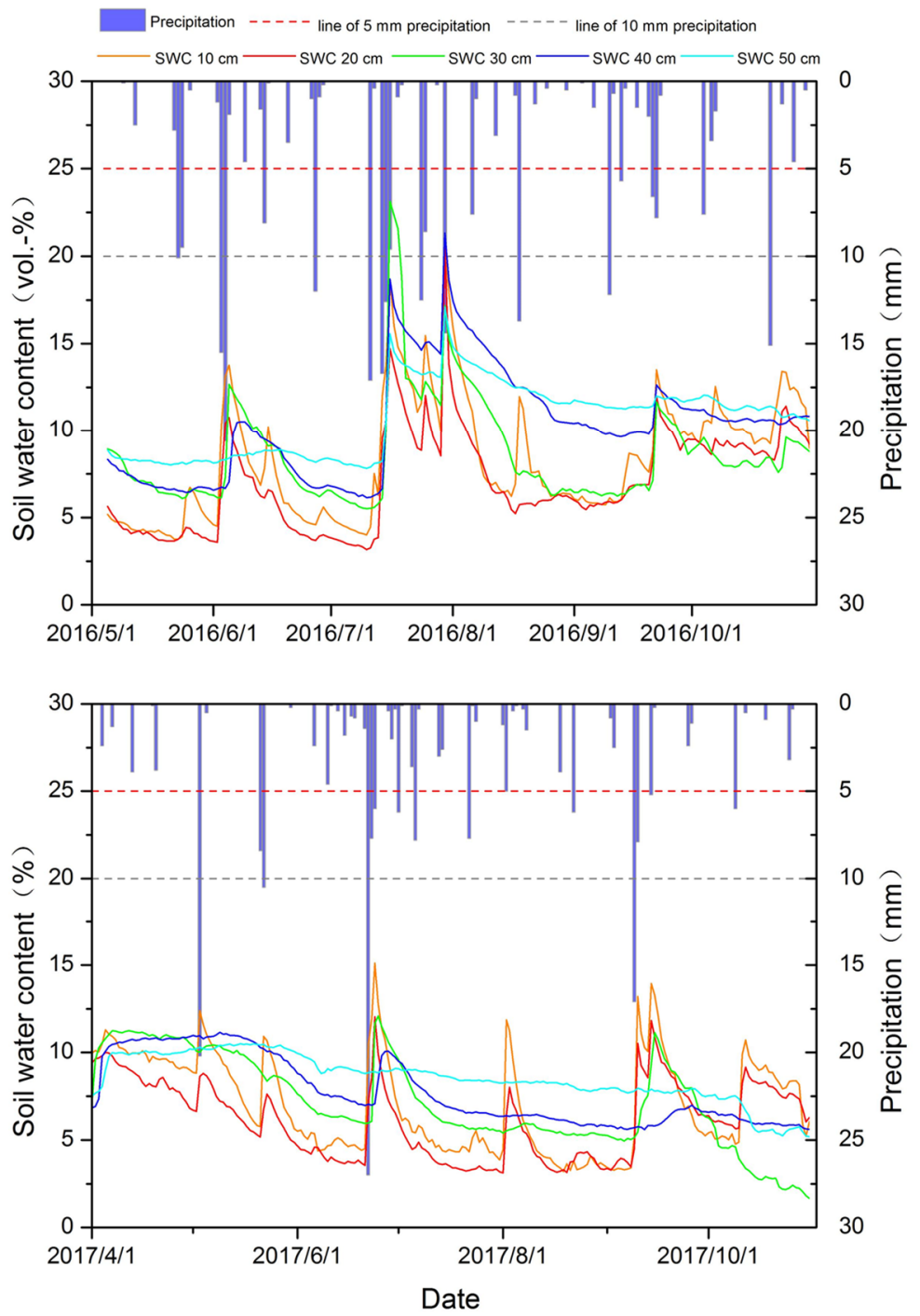

Figure 6. Dynamic of soil water content (SWC) between $10 \mathrm{~cm}$ and $50 \mathrm{~cm}$ and precipitation events during the growing season in different precipitation years. 
Table 3. SWC at 10-50 $\mathrm{cm}$ for each month during the growing season in different precipitation years.

\begin{tabular}{|c|c|c|c|c|c|c|c|}
\hline Year & SWC & Month & $10 \mathrm{~cm}$ & $20 \mathrm{~cm}$ & $30 \mathrm{~cm}$ & $40 \mathrm{~cm}$ & $50 \mathrm{~cm}$ \\
\hline \multirow{9}{*}{2016} & \multirow{8}{*}{ SWC (vol. \%) } & April & 5.61 & 5.94 & 6.74 & 6.26 & 7.41 \\
\hline & & May & 4.70 & 4.15 & 7.01 & 7.00 & 8.25 \\
\hline & & June & 7.40 & 5.88 & 8.45 & 8.26 & 8.53 \\
\hline & & July & 10.16 & 8.14 & 10.78 & 11.59 & 11.23 \\
\hline & & August & 8.56 & 7.16 & 9.43 & 13.32 & 12.82 \\
\hline & & September & 8.07 & 7.39 & 7.67 & 10.53 & 11.56 \\
\hline & & October & 10.69 & 9.40 & 8.54 & 10.73 & 11.31 \\
\hline & & Growing season & 8.35 & 7.08 & 8.69 & 10.32 & 10.68 \\
\hline & \multicolumn{2}{|c|}{ CV (\%) } & 41.4 & 40.3 & 34.7 & 30.3 & 19.9 \\
\hline \multirow{9}{*}{2017} & \multirow{8}{*}{ SWC (vol. \%) } & April & 9.91 & 8.65 & 10.78 & 10.30 & 9.64 \\
\hline & & May & 8.56 & 6.63 & 9.48 & 10.50 & 10.34 \\
\hline & & June & 6.67 & 5.32 & 7.53 & 8.01 & 9.12 \\
\hline & & July & 4.95 & 3.89 & 6.50 & 7.28 & 8.64 \\
\hline & & August & 4.90 & 4.36 & 5.51 & 6.17 & 8.15 \\
\hline & & September & 7.37 & 7.08 & 7.30 & 6.14 & 7.80 \\
\hline & & October & 7.38 & 7.19 & 3.35 & 6.08 & 6.25 \\
\hline & & Growing season & 7.09 & 6.15 & 7.19 & 7.78 & 8.56 \\
\hline & \multicolumn{2}{|c|}{$\mathrm{CV}(\%)$} & 39.0 & 35.8 & 36.5 & 24.8 & 15.6 \\
\hline
\end{tabular}

The response of SWC at depths of 10-50 cm to precipitation events at different levels is shown in Figure 6. In general, the impact of a single small precipitation event on the SWC is limited, and it causes no measurable increase in SWC, even in the topmost depth $(10 \mathrm{~cm})$. Precipitation events that are greater than $10 \mathrm{~mm}$ can increase the water content in the deeper soil layers, although this effect is also related to the SWC prior to such events. For instance, the SWC at a depth of $50 \mathrm{~cm}$ during the growing season of 2017 showed a continuously decreasing trend, and even the $27 \mathrm{~mm}$ precipitation event that occurred on June 22nd failed to increase the SWC. In addition, it can be seen that continuous large precipitation events are more likely to increase the SWC in deeper soil layers.

According to Table 3, the SWC of the vegetation root layer $(0-30 \mathrm{~cm})$ generally showed a decreased distribution trend from the surface to the deeper layers and then an increase. In the different precipitation years, the least SWC occurred at a soil depth between $10 \mathrm{~cm}$ and $30 \mathrm{~cm}$. Two possible reasons may explain this. First, with respect to the water supply, variations in SWC that are caused by small precipitation events (which were dominant) were mainly concentrated within the first $10 \mathrm{~cm}$. Second, with respect to the water absorption zone of desert vegetation, the $10-30 \mathrm{~cm}$ layer is the main root system distribution zone of shallow-rooted vegetation. Therefore, the water uptake of roots may also cause a decrease in SWC within the 10-30 cm layer. In terms of the CV of SWC in each layer for different precipitation years, the SWC dynamics in each layer during the humid year were more severe than in the drought year. Overall, the SWC dynamics was greater when the soil depth was shallower. However, in the drought year of 2017, the CV of $30 \mathrm{~cm}$ depth was larger than that of $20 \mathrm{~cm}$ depth. This exception could have been caused on the one hand by differences in precipitation characteristics of different years, and on the other hand by adjustments in the water use strategy of vegetation in the drought year. SWC differences in each soil layer caused by root water uptake during different precipitation or water stress years in arid and semiarid ecosystems require further study.

\subsubsection{Correlation between SWC of Each Layer in Different Precipitation Years}

Hydraulic connection of different layers changes in different hydrological years (wet year or dry year), which could affect hydrological and nutrient cycles in soil, as well as water utilization of soil organisms. The correlation between SWC of each layer in different precipitation years is shown in Table 4. 
Table 4. Correlation between SWC of each soil layer in different precipitation years.

\begin{tabular}{cccccc}
\hline $2017^{2016}$ & $10 \mathbf{c m}$ & $20 \mathbf{c m}$ & $\mathbf{3 0} \mathbf{c m}$ & $\mathbf{4 0} \mathbf{~ c m}$ & $\mathbf{5 0} \mathbf{~ c m}$ \\
\hline $10 \mathrm{~cm}$ & 1.00 & $0.95^{* *}$ & $0.76^{* *}$ & $0.75^{* *}$ & $0.68^{* *}$ \\
$20 \mathrm{~cm}$ & $0.93^{* *}$ & $1.00^{* *}$ & $0.77^{* *}$ & $0.79^{* *}$ & $0.73^{* *}$ \\
$30 \mathrm{~cm}$ & $0.53^{* *}$ & $0.46^{* *}$ & 1.00 & $0.80^{* *}$ & $0.64^{* *}$ \\
$40 \mathrm{~cm}$ & $0.44^{* *}$ & $0.33^{* *}$ & $0.82^{* *}$ & 1.00 & $0.95^{* *}$ \\
$50 \mathrm{~cm}$ & $0.16^{*}$ & $-0.02^{\mathrm{ns}}$ & $0.79^{* *}$ & $0.83^{* *}$ & 1.00 \\
\hline
\end{tabular}

Correlation between SWC of each soil layer is calculated by daily SWC. Yellow area in upper right table is the SWC correlation coefficient of each layer in 2016; blue area in lower left is that in 2017. ${ }^{* *}$ indicates a significant correlation at level of $p<0.01,{ }^{*}$ indicates a significant correlation at level of $p<0.05$, and ns indicates no significant correlation.

The correlation coefficient between $30 \mathrm{~cm}$ and $40 \mathrm{~cm}$ and that between $30 \mathrm{~cm}$ and $50 \mathrm{~cm}$ in the drought year were greater than in the humid year. However, the correlation coefficients of SWC for all the other layers were greater in the humid year than in the drought year. The close relationship between each soil layer in the humid year was more evident in the humid year (2016) than in the drought year (2017). When considering the different precipitation years, the correlations between SWC in the upper layers and lower layers were obviously stronger during the humid year, which indicates that more rainfall infiltrated into deeper layers and the SWC of each layer above increased correspondingly. In the drought year, however, the correlation between SWC in the $20 \mathrm{~cm}$ layer and that of the deeper soil layer was much lower, and the correlation between SWC in the $20 \mathrm{~cm}$ and $50 \mathrm{~cm}$ layers was even negative, which reflects that the influence of precipitation on SWC was more concentrated in the surface layer above $20 \mathrm{~cm}$ in the drought year of 2017. In addition, a comparison between SWC correlation coefficients in adjacent layers shows that that between $10 \mathrm{~cm}$ and $20 \mathrm{~cm}$ and that between $40 \mathrm{~cm}$ and $50 \mathrm{~cm}$ soil layers were larger than those of other adjacent layers in both the humid and drought years.

\subsection{Response of $E T_{a}$ of Shallow-Rooted Vegetation to Precipitation Pulses}

Due to the larger sample size of precipitation events, the humid year 2016 was selected as an instance to analyze the response of $\mathrm{ET}_{\mathrm{a}}$ to precipitation pulses.

\subsubsection{Variations in $\mathrm{ET}_{\mathrm{a}}$ during Growing Season}

Table 5 shows the variations in $\mathrm{ET}_{\mathrm{a}}$ during the growing season in 2016.

Table 5. Variations in actual evapotranspiration $\left(\mathrm{ET}_{\mathrm{a}}\right)$ during growing season of 2016 (Additionally given is the sum $\mathrm{ET}_{\mathrm{a}}$ over the growing season).

\begin{tabular}{|c|c|c|c|c|c|}
\hline Period & $\mathrm{ET}_{\mathrm{a}}(\mathrm{mm})$ & Precipitation (mm) & $\mathrm{ET}_{\max }(\mathrm{mm} / \mathrm{d})$ & $\mathrm{ET}_{\min }(\mathrm{mm} / \mathrm{d})$ & $\mathrm{ET}_{\text {ave }}(\mathrm{mm} / \mathrm{d})$ \\
\hline April & -23.34 & 1.40 & -1.60 & -0.39 & -0.78 \\
\hline May & -40.63 & 26.60 & -2.70 & -0.59 & -1.31 \\
\hline June & -83.55 & 71.20 & -4.85 & -0.67 & -2.78 \\
\hline July & -87.61 & 93.20 & -5.65 & -0.23 & -2.83 \\
\hline August & -58.44 & 28.40 & -5.78 & -0.46 & -1.89 \\
\hline September & -19.33 & 39.30 & -2.17 & -0.10 & -0.62 \\
\hline October & -27.50 & 34.20 & -2.52 & -0.10 & -0.89 \\
\hline Growing season & -340.40 & 294.30 & -5.78 & -0.10 & -1.59 \\
\hline
\end{tabular}

The minus sign indicates water dissipation by evapotranspiration. $\mathrm{ET}_{\max }$ and $\mathrm{ET}_{\min }$ are maximum and minimum values of daily $\mathrm{ET}_{\mathrm{a}}$ in the corresponding month, respectively. $\mathrm{ET}_{\mathrm{ave}}$ is the average daily $\mathrm{ET}_{\mathrm{a}}$ in the corresponding month.

The maximum $\mathrm{ET}_{\mathrm{a}}$ during the growing season occurred in July $(-2.83 \mathrm{~mm} / \mathrm{d})$, followed by June $(-2.78 \mathrm{~mm} / \mathrm{d})$, and this was obviously related to the high temperatures and rich precipitation during these two months. The maximum amount of daily $\mathrm{ET}_{\mathrm{a}}(-5.78 \mathrm{~mm} / \mathrm{d})$ occurred in August, followed by July $(-5.65 \mathrm{~mm} / \mathrm{d})$ and June $(-4.85 \mathrm{~mm} / \mathrm{d})$. This indicates that, under strong evapotranspiration, the effects of small precipitation events of $0-5 \mathrm{~mm}$ were limited with respect to the stable accumulation or 
assimilation of vegetation biomass. However, different studies have shown that small precipitation events have an irreplaceable role in promoting microbial activities in epipedon and maintaining the ecological functions of shallow root vegetation [38,39]. The average minimum daily $\mathrm{ET}_{\mathrm{a}}$ of $-0.10 \mathrm{~mm} / \mathrm{d}$ occurred in both September and October, and the average maximum daily $\mathrm{ET}_{\mathrm{a}}$ occurred in July $(-2.83 \mathrm{~mm} / \mathrm{d})$, followed by June $(-2.78 \mathrm{~mm} / \mathrm{d})$. The $\mathrm{ET}_{\mathrm{a}}$ of the entire growing season was larger than the amount of precipitation within the same period, which could be due to previous soil water storage during the non-growing season and condensate supplements [40-42]. Figure 7 shows the periodic variations in $\mathrm{ET}_{\mathrm{a}}$ and the time at which dew was deposited during the precipitation interval.

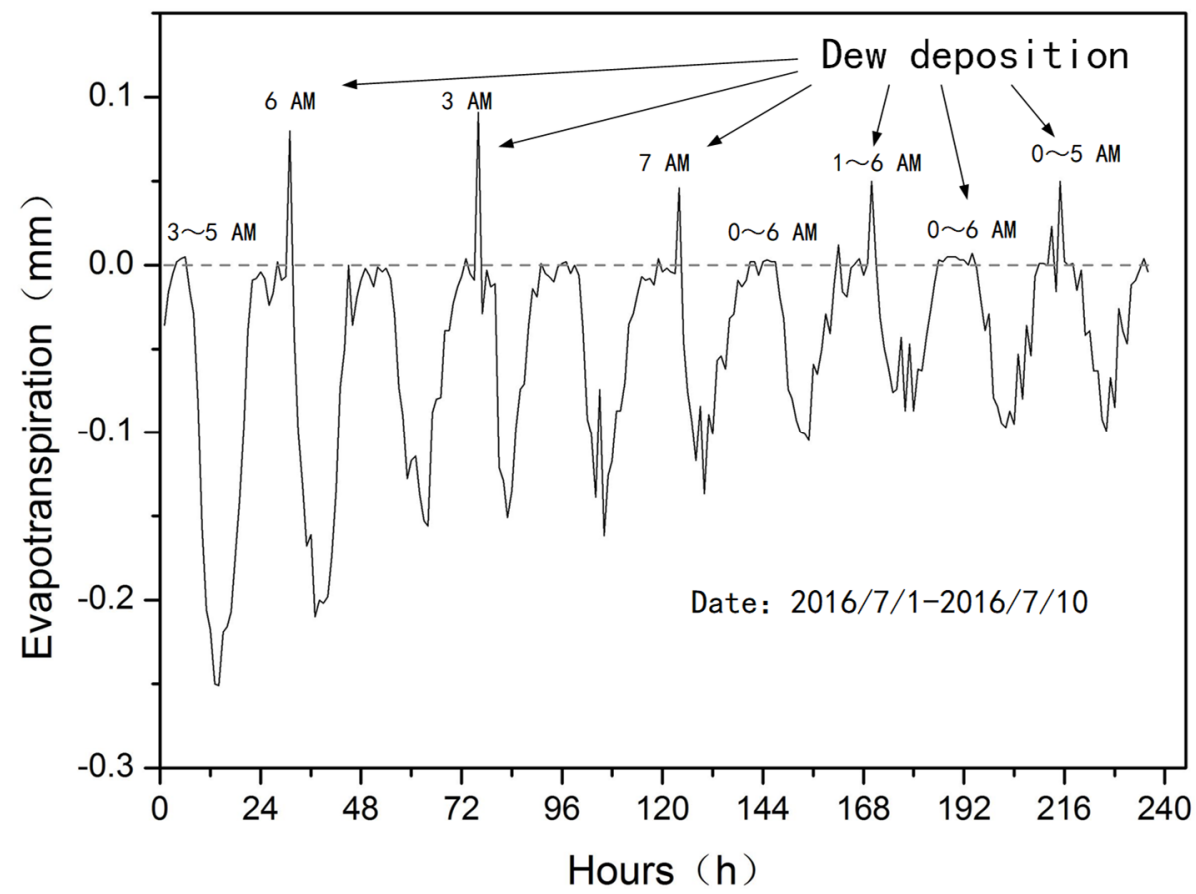

Figure 7. Dew deposition replenishment process between two precipitation events. The curves above the dashed line show the time when dew was deposited (usually in the early morning), and the fractions below show $\mathrm{ET}_{\mathrm{a}}$ during the precipitation interval of 1 July 2016-10 July 2016.

\subsubsection{Evapotranspiration Mode during Precipitation Interval}

Different interpulse periods formed between precipitation pulse events caused variations in SWC. SWC dynamics directly affect the physiological activity of vegetation and microorganisms, and they lead to different substance and energy cycle processes, which result in spatial and temporal heterogeneity of arid and semiarid ecosystems.

Through the continuous observation of the $\mathrm{ET}_{\mathrm{a}}$ during the growing season, combined with observations of precipitation and SWC, the different evapotranspiration modes during precipitation intervals were obtained and they are shown in Figure 8. After a sufficient amount of precipitation, a stable evapotranspiration mode is initiated under the adequate water supply, as shown in Figure 8a; this is known here as Interpulse mode I. In this mode, the amounts of daily $\mathrm{ET}_{\mathrm{a}}$ are similar and close to each other and close to that of potential evapotranspiration, and this corresponds to the first phase in Figure 8d. In particular, the start and end times of this phase are from 17 July 2016 to 23 July 2016, during the study period. Prior to the beginning of this phase, $56.4 \mathrm{~mm}$ of continuous precipitation fully supplied the soil moisture in each layer, and the average daily $\mathrm{ET}_{\mathrm{a}}$ was $-4.3 \mathrm{~mm} / \mathrm{d}$. The evapotranspiration intensity in this phase was mainly determined by the atmospheric evaporation capacity (temperature, humidity, and wind speed) and the water absorption capacity of the vegetation. With the continuous reduction in soil moisture, the SWC began to fall below a certain threshold, and evapotranspiration entered a daily attenuation phase due to water stress, which corresponds to the 
second phase (Interpulse mode II), as shown in Figure 8d. As shown in Figure $8 \mathrm{~b}$ a continuous rainless period occurred in the first ten days of July 2016 during Interpulse mode II, and there was no effective soil moisture supplement. Hence, the daily $\mathrm{ET}_{\mathrm{a}}$ decreased with a decrease in SWC, and the average daily $\mathrm{ET}_{\mathrm{a}}$ in the period was $-1.2 \mathrm{~mm} / \mathrm{d}$. The evapotranspiration intensity in this phase was affected by the combined effect of SWC, the atmospheric evaporation capacity, and the water absorption capacity of vegetation. With a further reduction in the SWC, the $\mathrm{ET}_{\mathrm{a}}$ re-entered a stable evapotranspiration mode under the extreme dry condition, corresponding to the third phase (Interpulse mode III) of Figure $8 \mathrm{~d}$. The SWC was extremely low in this phase and it was even lower than that of the wilting coefficient of vegetation. Therefore, the vegetation began to reduce its physiological activities to adapt to the extreme dry environment, resulting in stomatal closure and root breaking [37,38]. Meanwhile, due to the extremely low soil moisture transport capacity in this phase, the soil surface formed a dry soil layer, and evaporation occurred at the bottom and then diffused into the atmosphere as water vapor through the dry soil layer. This entire process was slow and stable. The evapotranspiration capacity in this phase was determined by the water vapor diffusion capacity of the dry soil layer. As shown in Figure 8c, a continuous drought occurred in mid-August, and the average daily $\mathrm{ET}_{\mathrm{a}}$ was only $-0.61 \mathrm{~mm} / \mathrm{d}$ from 26 to 30 August. Daily $\mathrm{ET}_{\mathrm{a}}$ and temperature had similar periodical change characteristics, which shows that $\mathrm{ET}_{\mathrm{a}}$ was mainly affected by temperature during the day.
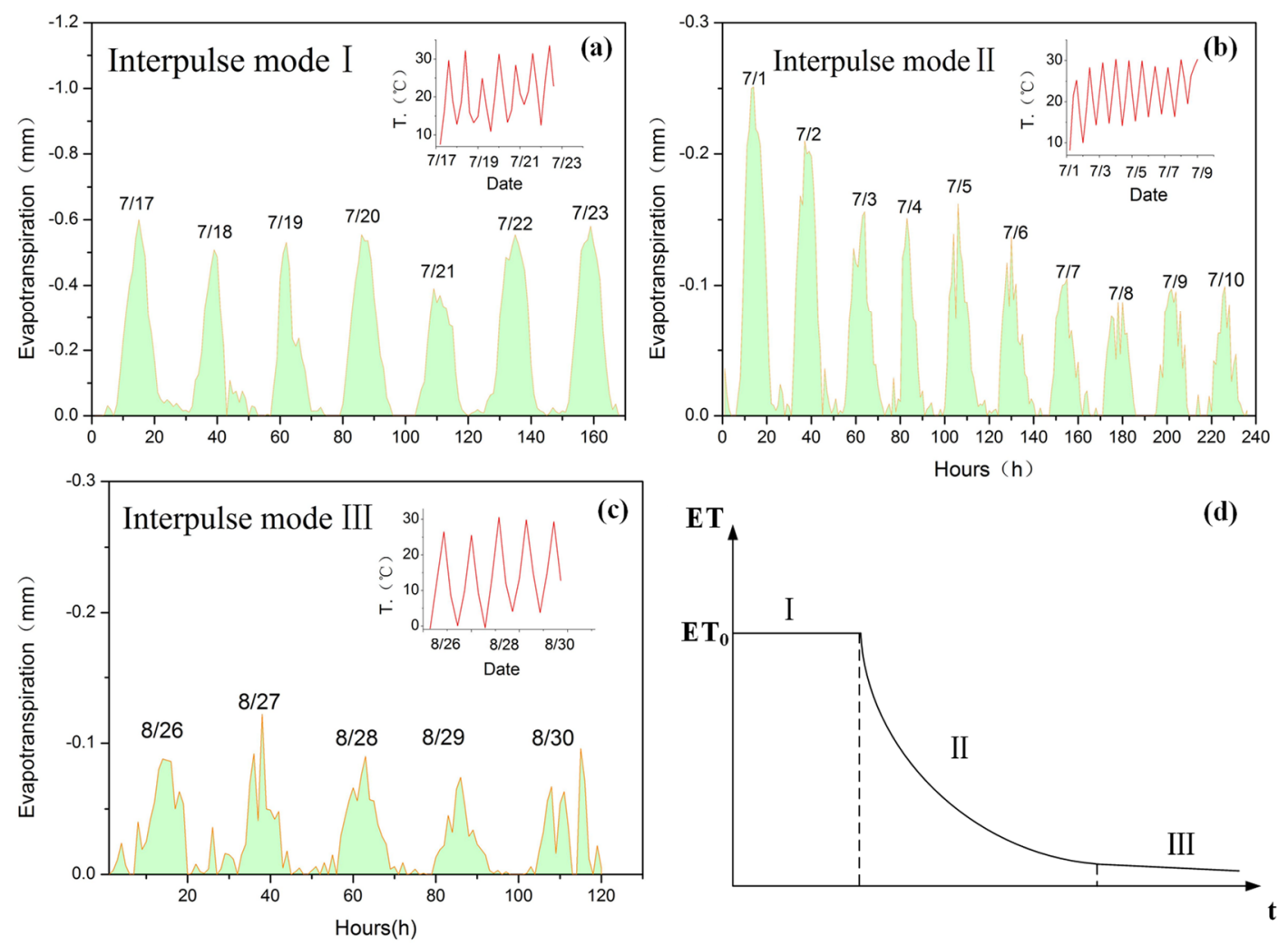

Figure 8. Interpulse mode of $\mathrm{ET}_{\mathrm{a}}$. (a) Interpulse mode I: Stable evapotranspiration mode (sufficient water content condition); (b) Interpulse mode II: Attenuated evapotranspiration mode (water stress appears); (c) Interpulse mode III: Stable evapotranspiration mode (extreme dry condition). The numbers in the graph (a), (b), (c) refer to the respective dates; and, (d) Scheme of interpulse evapotranspiration.

\subsection{Coupling Process Relating to Multi-Water Variations}

The coupling of SWC and evapotranspiration variations under precipitation pulses was analyzed for July 2016 and it is shown in Figure 9.

Figure 9 also shows that the precipitation events mainly occurred in July 2016 and they were relatively concentrated, providing a monthly precipitation amount of $93.2 \mathrm{~mm}$. In early July, after a 
continuous rainless period, the $\mathrm{ET}_{\mathrm{a}}$ and the SWC in each soil layer decreased continuously (Interpulse mode II (Figure 8)). Continuous precipitation occurred between 11 and 16 July, and soil moisture in each soil layer was fully supplied. A stable evapotranspiration phase began in the following period (17 to 23 July) (Interpulse mode I). The SWC of each soil layer began to decrease gradually in this phase but remained in the high value interval (higher than the stable evaporation threshold). Figure 9 shows that the temperature began to drop between the precipitation events, but it gradually increased between the precipitation events. In this drying-wetting conversion process, the temperature change directly influenced the evapotranspiration process. In addition, the $\mathrm{ET}_{\mathrm{a}}$ was generally low when the precipitation event occurred, due to the lower temperature in the precipitation process and the higher atmospheric humidity, which inhibited the evapotranspiration process.

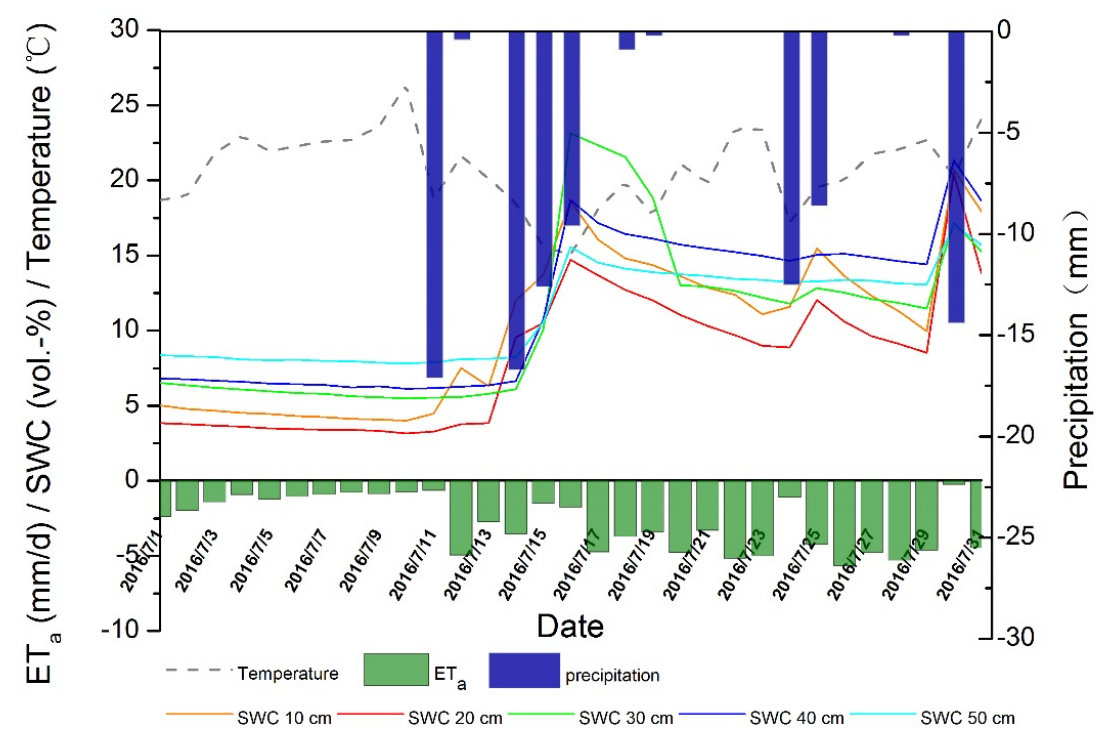

Figure 9. Coupling between variations in multi-water processes.

Table 6 shows the correlations between $\mathrm{ET}_{\mathrm{a}}$ and SWC in each soil layer. The soil layer at $50 \mathrm{~cm}$ has the highest correlation between $\mathrm{ET}_{\mathrm{a}}$ and $\mathrm{SWC}$, followed by $40 \mathrm{~cm}$ and then $10 \mathrm{~cm}$. This is because the root depth of the vegetation at the study site is generally no more than $40 \mathrm{~cm}$. When the moisture content in the soil layer at $40 \mathrm{~cm}$ to $50 \mathrm{~cm}$ is increased by precipitation, the SWC of each layer is relatively high and the $\mathrm{ET}_{\mathrm{a}}$ is relatively large. However, when the SWC in this layer decreases, which indicates that the upper layer soil is continuously losing water under water stress, the $\mathrm{ET}_{\mathrm{a}}$ shows a corresponding decreasing trend. The change in SWC in the layer at $40-50 \mathrm{~cm}$ below the vegetation root layer is relatively stable and it can be considered to be characteristic of the overall soil water status. The reason for the high correlation between the SWC in the $10 \mathrm{~cm}$ soil layer and the $\mathrm{ET}_{\mathrm{a}}$ may be that it is closer to the soil surface and soil evaporation has a greater influence on this layer. The soil layer of $10-30 \mathrm{~cm}$ is the main root distribution zone of shallow-rooted vegetation. The soil moisture of this region is affected by the water uptake process of roots and it also affected by water flux transmission process between the upper and lower layers. Therefore, the SWC dynamics are more active in this layer during the vigorous growth period of vegetation, which results in a low correlation with $\mathrm{ET}_{\mathrm{a}}$.

Table 6. Correlation between $\mathrm{ET}_{\mathrm{a}}$ and SWC of each layer for 2016.

\begin{tabular}{cccccc}
\hline Correlation & $\mathbf{1 0} \mathbf{~ c m}$ & $\mathbf{2 0} \mathbf{~ c m}$ & $\mathbf{3 0} \mathbf{~ c m}$ & $\mathbf{4 0} \mathbf{~ c m}$ & $\mathbf{5 0} \mathbf{~ c m}$ \\
\hline $\mathrm{ET}_{\mathrm{a}}(\mathrm{mm})$ & $0.47^{* *}$ & $0.38^{*}$ & $0.40^{*}$ & $0.49^{* *}$ & $0.50^{* *}$ \\
$\mathrm{CV}$ of SWC & $50.6 \%$ & $55.8 \%$ & $50.6 \%$ & $43.4 \%$ & $27.5 \%$ \\
\hline
\end{tabular}

** indicates a significant correlation at $p<0.01$ level, and * indicates a significant correlation at $p<0.05$ level. 


\section{Conclusions}

This study analyzes the coupling of SWC and $\mathrm{ET}_{\mathrm{a}}$ following precipitation pulses in a desert steppe. The concept of the precipitation interval ratio (P/I) is proposed, as this can be used to effectively evaluate the degree of water stress during different drying-wetting cycles. Three modes of interpulse $\mathrm{ET}_{\mathrm{a}}$ in this arid environment under different SWCs are identified and discussed. These results improve our understanding of the hydrological cycle mechanism of desert steppe. The results of this research can also provide data support for ecological restoration and desertification control. The main conclusions are as follows:

(1) The extreme variability or unpredictability of precipitation intervals in arid and semiarid ecosystems are important factors affecting soil moisture distribution and vegetation growth. By using the precipitation interval ratio $(\mathrm{P} / \mathrm{I})$, water stress situations in different drying-wetting cycles can be directly compared and can thus reflect the annual variations in the drying-wetting cycle.

(2) The impact of a single small precipitation event on the SWC is limited, and such events do not even cause a significant increase in the SWC of the $10 \mathrm{~cm}$ soil layer. Precipitation events that are continuous or greater than $10 \mathrm{~mm}$ can cause an SWC increase in deeper soil layers, but this also depends on initial SWC. In addition, a closer correlation between the soil layers for the humid year than for the drought year.

(3) The maximum daily $\mathrm{ET}_{\mathrm{a}}$ of $-5.78 \mathrm{~mm} / \mathrm{d}$ occurred in August during the growing season of 2016. With the influence of strong evapotranspiration, the effect of small precipitation events of 0-5 mm on the plant assimilation was limited. In 2016, the amount of $\mathrm{ET}_{\mathrm{a}}$ was greater than that of precipitation for the same period during the whole growing season, and this water deficit was related to previous soil water storage and condensation water.

(4) According to continuous $\mathrm{ET}_{\mathrm{a}}$ observations during the growing season of 2016, there were three interpulse evapotranspiration modes during the different interval periods: a stable mode under a sufficient water content condition (17 July-23 July, $-4.3 \mathrm{~mm} / \mathrm{d}$ ), an attenuation mode ( 1 July-11 July, $-1.2 \mathrm{~mm} / \mathrm{d}$ ), and a stable evapotranspiration mode under extreme drought conditions (26 August-30 August, $-0.61 \mathrm{~mm} / \mathrm{d}$ ).

(5) During the vigorous growth period of July 2016, the $50 \mathrm{~cm}$ soil layer showed the highest correlation between $\mathrm{ET}_{\mathrm{a}}$ and SWC, followed by the $40 \mathrm{~cm}$ and $10 \mathrm{~cm}$ layers. The layer from $10-30 \mathrm{~cm}$ is the main root distribution zone of shallow-rooted vegetation at the study site, and this zone undergoes the most drastic changes due to root water uptake and water flux transmission processes between the upper and lower layers; therefore, its correlation with $\mathrm{ET}_{\mathrm{a}}$ is relatively weak.

It is of great significance to analyze interrelated multi-water processes under natural conditions to understand the hydrological cycle in desert steppe. However, our knowledge about the feedback mechanism between soil organisms (plant and microbe) and hydrological cycles of soil in arid and semi-arid regions remain insufficient. Therefore, further research should consider the water-use strategy of biomes in arid and semi-arid regions.

Author Contributions: Conceptualization, Y.S.; Data curation, X.X. and T.L.; Formal analysis, Y.L. and W.H.; Investigation, J.W.; Methodology, Y.S.; Resources, W.W.; Supervision, Z.G.; Writing-review \& editing, Y.L. and J.W.

Funding: This research was funded by the Basic Scientific Research Foundation Special Project of Institute of Water Resources and Hydropower Research (MK2016J16, MK2017J01), the National Natural Science Foundation of China (51779156), the Natural Science Foundation of Inner Mongolia Autonomous Region of China (2017MS0516), and the special fund of State Key Laboratory of Simulation and Regulation of Water Cycle in River Basin (Grant NO. SKL2018TS01).

Conflicts of Interest: The authors declare no conflict of interest. 


\section{References}

1. Peters, D.P.C.; Bestelmeyer, B.T.; Herrick, J.E.; Fredrickson, E.L.; Monger, H.C.; Havstad, K.M. Disentangling Complex Landscapes: New Insights into Arid and Semiarid System Dynamics. Bioscience 2006, 56, 491-501. [CrossRef]

2. Smith, S.D.; Huxman, T.E.; Zitzer, S.F.; Charlet, T.N.; Housman, D.C.; Coleman, J.S.; Fenstermaker, L.K.; Seemann, J.R.; Nowak, R.S. Elevated $\mathrm{CO}_{2}$ increases productivity and invasive species success in an arid ecosystem. Nature 2000, 408, 79-82. [CrossRef] [PubMed]

3. Muñoz-Rojas, M.; Erickson, T.E.; Martini, D.; Dixon, K.W.; Merritt, D.J. Soil physicochemical and microbiological indicators of short, medium and long term post-fire recovery in semi-arid ecosystems. Ecol. Indic. 2016, 63, 14-22. [CrossRef]

4. Cheng, Y.; Zhan, H.; Yang, W.; Dang, H.; Li, W. Is annual recharge coefficient a valid concept in arid and semi-arid regions? Hydrol. Earth Syst. Sci. 2017, 21, 1-29. [CrossRef]

5. Huxman, T.E.; Snyder, K.A.; Tissue, D.; Leffler, A.J.; Ogle, K.; Pockman, W.T.; Sandquist, D.R.; Potts, D.L.; Schwinning, S. Precipitation pulses and carbon fluxes in semiarid and arid ecosystems. Oecologia 2004, 141, 254-268. [CrossRef] [PubMed]

6. Schwinning, S.; Sala, O.E.; Loik, M.E.; Ehleringer, J.R. Thresholds, memory, and seasonality: understanding pulse dynamics in arid/semi-arid ecosystems. Oecologia 2004, 141, 191-193. [CrossRef] [PubMed]

7. Noymeir, I. Desert Ecosystems: Environment and Producers. Annu. Rev. Ecol. Syst. 1973, 4, 25-51. [CrossRef]

8. Loik, M.E.; Breshears, D.D.; Lauenroth, W.K.; Belnap, J. A multi-scale perspective of water pulses in dryland ecosystems: climatology and ecohydrology of the western USA. Oecologia 2004, 141, 269-281. [CrossRef]

9. Sala, O.E.; Gherardi, L.A.; Peters, D.P.C. Enhanced precipitation variability effects on water losses and ecosystem functioning: Differential response of arid and mesic regions. Clim. Chang. 2015, 131, $213-227$. [CrossRef]

10. Heislerwhite, J.L.; Knapp, A.K.; Kelly, E.F. Increasing precipitation event size increases aboveground net primary productivity in a semi-arid grassland. Oecologia 2008, 158, 129-140. [CrossRef]

11. Shafran-Nathan, R.; Svoray, P. The resilience of annual vegetation primary production subjected to different climate change scenarios. Clim. Chang. 2013, 118, 227-243. [CrossRef]

12. Pei, S.; Fu, H.; Wan, C. Changes in soil properties and vegetation following exclosure and grazing in degraded Alxa desert steppe of Inner Mongolia, China. Agric. Ecosyst. Environ. 2008, 124, 33-39. [CrossRef]

13. Li, C.; Hao, X.; Zhao, M.; Han, G.; Walterd, W. Influence of historic sheep grazing on vegetation and soil properties of a Desert Steppe in Inner Mongolia. Agric. Ecosyst. Environ. 2008, 128, 109-116. [CrossRef]

14. Parton, W.J.; Scurlock, J.M.O.; Ojima, D.S.; Schimel, D.S.; Hall, D.O.; Members, S.G. Impact of climate change on grassland production and soil carbon worldwide. Glob. Chang. Biol. 2010, 1, 13-22. [CrossRef]

15. Song, Y.; Guo, Z.; Lu, Y.; Yan, D.; Liao, Z.; Liu, H.; Cui, Y. Pixel-Level Spatiotemporal Analyses of Vegetation Fractional Coverage Variation and Its Influential Factors in a Desert Steppe: A Case Study in Inner Mongolia, China. Water 2017, 9, 478. [CrossRef]

16. Wang, K.; Deng, L.; Ren, Z.; Li, J.; Shangguan, Z. Grazing exclusion significantly improves grassland ecosystem C and N pools in a desert steppe of Northwest China. CATENA 2016, 137, 441-448. [CrossRef]

17. Verstraete, M.M.; Brink, A.B.; Scholes, R.J.; Beniston, M.; Smith, M.S. Climate change and desertification: Where do we stand, where should we go? Glob. Planet. Chang. 2008, 64, 105-110. [CrossRef]

18. Nicholson, S.E.; Tucker, C.J.; Ba, M.B. Desertification, Drought, and Surface Vegetation: An Example from the West African Sahel. Bull. Am. Meteorol. Soc. 2010, 79, 815-829. [CrossRef]

19. Zhan, X.; Li, L.; Cheng, W. Restoration of Stipa krylovii steppes in Inner Mongolia of China: Assesment of seed banks and vegetation composition. J. Arid Environ. 2007, 68, 298-307. [CrossRef]

20. Reynolds, J.F.; Smith, D.M.; Lambin, E.F.; Turner, B.L., 2nd; Mortimore, M.; Batterbury, S.P.; Downing, T.E.; Dowlatabadi, H.; Fernández, R.J.; Herrick, J.E.; et al. Global Desertification: Building a Science for Dryland Development. Science 2007, 316, 847-851. [CrossRef]

21. Sugita, M.; Yoshizawa, S.; Byambakhuu, I. Limiting factors for nomadic pastoralism in Mongolian steppe: A hydrologic perspective. J. Hydrol. 2015, 524, 455-467. [CrossRef]

22. Reynolds, J.F.; Kemp, P.R.; Ogle, K.; Fernández, R.J. Modifying the 'pulse-reserve' paradigm for deserts of North America: precipitation pulses, soil water, and plant responses. Oecologia 2004, 141, 194-210. [CrossRef]

23. Wilcox, B.P.; Breshears, D.D.; Seyfried, M.S. Rangelands, Water Balance on. Encycl. Water Sci. 2003. [CrossRef] 
24. Feng, X.; Fu, B.; Piao, S.; Wang, S.; Ciais, P.; Zeng, Z.; Lü, Y.; Zeng, Y.; Li, Y.; Jiang, X. Revegetation in China's Loess Plateau is approaching sustainable water resource limits. Nat. Clim. Chang. 2016, 6, 1019-1022. [CrossRef]

25. Milly, P.C.D.; Dunne, K.A. Potential evapotranspiration and continental drying. Nat. Clim. Chang. 2016, 6, 946-949. [CrossRef]

26. Esch, E.H.; Lipson, D.; Cleland, E.E. Direct and indirect effects of shifting rainfall on soil microbial respiration and enzyme activity in a semi-arid system. Plant Soil 2017, 411, 333-346. [CrossRef]

27. Liu, W.; Zhe, Z.; Wan, S. Predominant role of water in regulating soil and microbial respiration and their responses to climate change in a semiarid grassland. Glob. Chang. Biol. 2010, 15, 184-195. [CrossRef]

28. Leffler, A.J.; Ryel, R.J.; Hipps, L.; Ivans, S.; Caldwell, M.M. Carbon acquisition and water use in a Northern Utah Juniperus osteosperma (Utah juniper) population. Tree Physiol. 2002, 22, 1221-1230. [CrossRef] [PubMed]

29. Yazdanpanah, N.; Mahmoodabadi, M.; Cerdà, A. The impact of organic amendments on soil hydrology, structure and microbial respiration in semiarid lands. Geoderma 2016, 266, 58-65. [CrossRef]

30. Schimel, D.S.; Braswell, B.H.; Holland, E.A.; Mckeown, R.; Ojima, D.S.; Painter, T.H.; Parton, W.J.; Townsend, A.R. Climatic, edaphic, and biotic controls over storage and turnover of carbon in soils. Glob. Biogeochem. Cycles 1994, 8, 279-293. [CrossRef]

31. Wang, Y.; Zhu, H.; Li, Y. Spatial heterogeneity of soil moisture, microbial biomass carbon and soil respiration at stand scale of an arid scrubland. Environ. Earth Sci. 2013, 70, 3217-3224. [CrossRef]

32. Olivera-Guerra, L.; Mattar, C.; Merlin, O.; Durán-Alarcón, C.; Santamaría-Artigas, A.; Fuster, R. An operational method for the disaggregation of land surface temperature to estimate actual evapotranspiration in the arid region of Chile. ISPRS J. Photogramm. 2017, 128, 170-181. [CrossRef]

33. Olivera-Guerra, L.E.; Merlin, O.; Mattar, C.; Durán-Alarcón, C.; Santamaría-Artigas, A.; Stefan, V. Combining meteorological and lysimeter data to evaluate energy and water fluxes over a row crop for remote sensing applications. In Proceedings of the 2015 IEEE International Geoscience and Remote Sensing Symposium (IGARSS), Milan, Italy, 26-31 July 2015.

34. Vargas, R.; Detto, M.; Baldocchi, D.D.; Allen, M.F. Multiscale analysis of temporal variability of soil $\mathrm{CO}_{2}$ production as influenced by weather and vegetation. Glob. Chang. Biol. 2010, 16, 1589-1605. [CrossRef]

35. Belnap, J.; Phillips, S.L.; Miller, M.E. Response of desert biological soil crusts to alterations in precipitation frequency. Oecologia 2004, 141, 306-316. [CrossRef] [PubMed]

36. Aguilera, L.E.; Armas, C.; Cea, A.P.; Gutiérrez, J.R.; Meserve, P.L.; Kelt, D.A. Rainfall, microhabitat, and small mammals influence the abundance and distribution of soil microorganisms in a Chilean semi-arid shrubland. J. Arid Environ. 2016, 126, 37-46. [CrossRef]

37. Zörner, J.; de Vries, M.P.; Beirle, S.; Sihler, H.; Veres, P.R.; Williams, J.; Wagner, T. Multi-satellite sensor study on precipitation-induced emission pulses of NOx from soils in semi-arid ecosystems. Atmos. Chem. Phys. 2016, 18, 1-39.

38. Sala, O.E.; Lauenroth, W.K. Small rainfall events: An ecological role in semiarid regions. Oecologia 1982, 53, 301-304. [CrossRef]

39. Nobel, P.S.; Sanderson, J. Rectifier-like Activities of Roots of Two Desert Succulents. J. Exp. Bot. 1984, 35, 727-737. [CrossRef]

40. Agam, N.; Berliner, P.R. Dew formation and water vapor adsorption in semi-arid environments-A review. J. Arid Environ. 2006, 65, 572-590. [CrossRef]

41. Zhang, Q.; Wang, S.; Yang, F.L.; Yue, P.; Yao, T.; Wang, W.Y. Characteristics of Dew Formation and Distribution, and Its Contribution to the Surface Water Budget in a Semi-arid Region in China. Bound-Lay Meteorol. 2015, 154, 317-331. [CrossRef]

42. Li, X.Y. Effects of gravel and sand mulches on dew deposition in the semiarid region of China. J. Hydrol. 2002, 260, 151-160. [CrossRef]

(C) 2019 by the authors. Licensee MDPI, Basel, Switzerland. This article is an open access article distributed under the terms and conditions of the Creative Commons Attribution (CC BY) license (http:/ / creativecommons.org/licenses/by/4.0/). 